\title{
Reforming Health Policy in Jordan: Finance and Allocating Public Expenditures: a Worldwide Review
}

\author{
Ali A.A. Rawabdeh ${ }^{* 1}$, Rami M. Tbaishat ${ }^{2}$, Ahmad Zakaria ${ }^{3}$ and Iman El Hajj Dib Zakaria4 \\ 'Basic Medical Sciences Department, Health Services Management Master Program, Faculty of Medicine, \\ Yarmouk University, Irbid, Jordan; alirawabdeh@hotmail.com, ali.rawabdeh@yu.edu.jo \\ 2Public Administration Department, Faculty of Economics and Administrative Sciences, P.O. Box: 566, \\ Yarmouk University, Irbid; Jordan rami.tbaishat@yu.edu.jo \\ ${ }^{3}$ Member of MIGRINTER, Poitiers University; Member of IFPO - Beyrouth Lebanon, Physical, Human, Economic and \\ regional Geography, Poitiers University, France; ahmadz.7677yahoo@yahoo.fr \\ ${ }^{4}$ Assistant Professor of Biology and Health, Faculty of Sciences Tripoli, Lebanese University; iman2h@yahoo.fr
}

\begin{abstract}
Background: This article offers evaluations of healthcare expenditures by sponsors that face increasing challenges as healthcare costs rise. Purposes: The aim of this action report is to ensure adequate health care services coupled with financial resources to fulfill the health challenges within the light-weight of the worse economic scenario. Methods: This article presents a read of healthcare spending in Jordan that focuses on the sectors that finance healthcare. Therefore, all the information published was used. Results: Jordan's government wouldn't be ready to continue providing health services at the present trend: fast increase in demand over publicly funded services within the absence efficiency gains (six types); reforms to create upon the strength of public and private sector improve quality of care and increase accessibility; and, enhance patient satisfaction and long-term financial sustainability. Conclusion: For the care system to be considered efficient and equitable the cash burden ought to be progressive throughout of pocket payments, and to cut back monetary barriers to access. Recommendation: There was a progressive impact of the reform on healthcare supplying and finance systems once contributor's expenses are used to build it; however, the findings don't seem to be conclusive.
\end{abstract}

Keywords: Equity, Financing, Efficiency, Expenditures, Health Care Delivery and Financing Systems Reform

\section{Introduction}

The pricy health system, safety and steadiness conditions, and therefore the effective development plans in Jordan play an essential role within the sustainable development of the kingdom.., 2

This article is designed to present a read of healthcare spending in Jordan that focuses on the sectors that finance or sponsor healthcare. These sources of funds are classified into insurance, out of pocket spending, other private revenues, and specific government programs. For national accounting, this structure is helpful in measurement changes in spending trends associated with policy initiatives within the government and private sectors, besides the amounts paid by every supplier. 3.4

In the 1990s, Jordan's total health expenditures represent $9.6 \%$ of GDP and dropped down to 8.7 in 2016 (Table 1). Reports show that the public sector is the largest source of funding which represents about $65.75 \%$ in 2014 (Table 2) followed by the private sector $31.75 \%$ and the rest is from donors and others.

The emerging main policy issue here is the high level of total health expenditures as a percentage of GDP compared with the ability to provide healthcare services at the current level of health indicators, quantity and quality of care and high level of spending on curative

${ }^{*}$ Author for correspondence 
Table 1. Health expenditures (\%of GDP)

\begin{tabular}{|c|c|c|c|c|c|c|c|c|c|c|c|c|c|}
\hline \multirow{2}{*}{$\begin{array}{l}\text { Comparison } \\
\text { countries-international } \\
\text { Arab World }\end{array}$} & \multirow{2}{*}{$\begin{array}{c}\text { Year } \\
2016 \\
4.8\end{array}$} & \multirow{2}{*}{$\begin{array}{l}\text { Neighbor- } \\
\text { ing and } \\
\text { regional } \\
\text { countries } \\
\text { comparison }\end{array}$} & \multicolumn{11}{|c|}{ Years } \\
\hline & & & ڤి & ఫั่ & 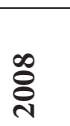 & ڤે̀े & 을 & $\overrightarrow{\widetilde{N}}$ & ำ & $\stackrel{m}{\stackrel{\sim}{*}}$ & ت্ণ & กั & $\stackrel{\circ}{\circ}$ \\
\hline East Asia \& Pacific & 6.7 & Egypt & 5 & 4 & 4 & 42 & 45 & 4 & 45 & & & & \\
\hline Euro area & 10.1 & & 5.1 & 4.6 & 4.6 & 4.3 & 4.5 & 4.9 & 4.5 & 4.0 & 4.1 & 5.1 & 4.6 \\
\hline European Union & 9.9 & Iraq & & & & & & & & & & & \\
\hline Europe \& Central Asia & 9.3 & & & 3.0 & 3.7 & 3.3 & 2.8 & 3.1 & 3.1 & 3.3 & 3.3 &.. & 3.0 \\
\hline $\begin{array}{l}\text { Latin America \& } \\
\text { Caribbean }\end{array}$ & 7.3 & Jordan & 9.6 & 8.7 & 9.5 & 8.0 & 8.3 & 7.9 & 7.3 & 7.4 & 6.2 & 9.6 & 8.7 \\
\hline $\begin{array}{l}\text { Least developed } \\
\text { countries: UN } \\
\text { classification }\end{array}$ & 4.7 & Kuwait & 2.5 & 1.9 & 3.8 & 2.7 & 2.6 & 2.5 & 2.5 & 3.1 & 4.0 & 2.5 & 1.9 \\
\hline $\begin{array}{l}\text { Middle East \& North } \\
\text { Africa }\end{array}$ & 5.4 & Oman & 3.0 & 2.0 & 2.8 & 2.7 & 2.5 & 2.5 & 2.8 & 3.4 & 3.8 & 3.0 & 2.0 \\
\hline OECD members & 12.4 & Qatar & 2.0 & 1.6 & 2.1 & 1.7 & 1.5 & 1.7 & 2.0 & 2.4 & 3.0 & 2.0 & 1.6 \\
\hline South Asia & 3.7 & $\begin{array}{l}\text { Saudi } \\
\text { Arabia }\end{array}$ & 4.2 & 2.8 & 4.0 & 3.4 & 3.6 & 3.9 & 4.3 & 5.0 & 5.8 & 4.2 & 2.8 \\
\hline Sub-Saharan Africa & 5.3 & Yemen Rep. & 4.1 & 5.1 & 5.3 & 5.1 & 5.0 & 5.7 & 5.7 & 5.6 & 5.9 & 4.1 & 5.1 \\
\hline World & 9.9 & & & & & & & & & & & & \\
\hline
\end{tabular}

Source: World Bank, 2018

Table 2. Health expenditures, 2008-2014

\begin{tabular}{|l|l|l|l|l|l|l|l|}
\hline & $\mathbf{2 0 0 8}$ & $\mathbf{2 0 0 9}$ & $\mathbf{2 0 1 0}$ & $\mathbf{2 0 1 1}$ & $\mathbf{2 0 1 2}$ & $\mathbf{2 0 1 3}$ & $\mathbf{2 0 1 4}$ \\
\hline $\begin{array}{l}\text { Health expenditures, nominal (million } \\
\text { JD) }\end{array}$ & 1381 & 1610 & 1537 & 1580 & 1665 & 1880 & \\
\hline Per capita healthcare expenditures (JD) & 236 & 269.3 & 251.5 & 252.5 & 260.6 & 231.8 & \\
\hline Per Capita GDP & 2753 & 2882 & 3069 & 3275 & 3438 & 2939 & \\
\hline $\begin{array}{l}\text { \% of government budget allocated to } \\
\text { healthcare }\end{array}$ & 10.16 & 10.52 & 9.76 & 9.14 & 10.50 & 11.0 & \\
\hline Public expenditures \% & 60.78 & 69.17 & 67.94 & 66.85 & 66.17 & 65.75 & \\
\hline Private expenditures \% & 38.24 & 29.80 & 30.27 & 31.34 & 31.88 & 31.75 & \\
\hline UNRWA & 0.69 & 0.59 & 0.75 & 0.67 & 0.75 & 0.74 & \\
\hline NGOs & 0.29 & 0.43 & 1.04 & 1.14 & 1.20 & 1.93 & \\
\hline Public expenditures \% of GDP & 5.21 & 6.59 & 5.57 & 5.16 & 5.02 & 5.18 & 5.19 \\
\hline Private expenditures \% of GDP & 3.37 & 2.93 & 2.62 & 2.56 & 2.56 & 2.70 & 2.26 \\
\hline Total expenditures \% of GDP & 8.58 & 9.52 & 8.19 & 7.72 & 7.58 & 7.88 & 7.45 \\
\hline $\begin{array}{l}\text { Pharmaceuticals expenditures as a \% of } \\
\text { total health Expenditures }\end{array}$ & 35.94 & 27.91 & 27.56 & 27.07 & 26.75 & 26.60 & \\
\hline $\begin{array}{l}\text { Pharmaceuticals expenditures as \% of } \\
\text { GDP }\end{array}$ & 3.08 & 2.66 & 2.26 & 2.09 & 2.03 & 2.10 & \\
\hline
\end{tabular}

Source: NHA, 2015 
care $85 \%$ and low level on spending of $15 \%$ on preventive services..,$\underline{6}$

The government of Jordan is committed to creating health services out there to all or any. The national health strategy is geared toward making a comprehensive healthcare system, utilizing both public and private service providers and covering all levels as well as the advanced healthcare provision to the poor. ${ }^{-1}-10$ A review of the recent trends in healthcare spending with temporary assessment of the foremost vital forces driving disbursal growth, finance of health expenditures with specific attention to the sources and uses of funds among the public sector and judge the efficiency and equity of the health system are bestowed measures to realize that goal. $, \underline{11}, \underline{12}$

\section{Problem}

The Jordanian health sector is the main sector that tortured by the inflexed refugees and out-boarder displaced population i.e., Iraqis, Syrians, Palestinians, etc. A high demand on health services were witnessed within the last two decades due to internal (population growth) and external pressures; country's restricted resources; epidemiologic transitions (lower prevalence of communicable diseases and high prevalence of noncommunicable disease), re-emergence of the entirely eradicated diseases i.e. T.B. and Malaria; poor quality of care; expected rise of young and elderly population; and, the rapid increase of costs of healthcare provision. An enormous effort is needed from the government to ensure adequate healthcare services coupled with financial resources, smart governance and increase productivities to produce a provision of safe, effective and efficient, equitable and affordable health services to fulfill the on top challenges within the light-weight of worse economic situation and money and slump. $-\underline{-9}, \underline{13}-\underline{15}$

\section{Aims and Objectives}

This article aims to ensure adequate healthcare services coupled with financial resources, good governance and increase productivities to provide a provision of safe, effective and efficient, equitable and affordable health services to meet the healthcare system challenges in the light of the worse economic situation and financial and economic crisis. Introduce a reformed strategy for healthcare system finance and delivery, increasing access healthcare to all, and enable effective and equitable access for uninsured and poor population in Jordan.

\section{Methods}

Data for this action report were gotten by suggested of sea of dispersed texture utilizing characterized watchwords and electronic databases were looked covering wide range period of more than 25 years commencing 1990, using content words and passage terms: Jordan, Arab world, health expenditures, healthcare system framework, healthcare financing framework, publicly funded health services, health system reform, health sector reform. In expansion, the reference list of disseminated studies was looked physically for present articles. To play down disposition and progress the value of this report researchers conducted a exhaustive examination of existing literature by implies of individual contact with senior officers at health authorities, government workplaces, and health sector divisions and key universal sources i.e., World Health Organization (WHO), World Bank, and local sources such as the Ministry of Health $(\mathrm{MOH})$, the Royal Medical Services (RMS), Jordan University and Jordan University of Science and Technology Teaching Hospitals (JUH, JUST), National Health Account (NHA), Private sector affiliation and Supreme Health Council. Qualified studies were those that centered on the Jordanian healthcare delivery and financing systems. Avoided studies were those that centered on the extensive outline and replicated considers. Two analysists (AR, $\mathrm{AK}$ ) autonomously screened the titles and unique of the recognized thinks about and duplications were outside. Studies considered qualified for full content screening were recovered for a full review. The analysists autonomously evaluated the papers for qualification and quality and met to resolve any discrepancies with respect to qualification and/or quality. The key highlights of the considers were summarized, tables and pertinent portrayal of healthcare delivery and financing frameworks was carried out.

As an action report, the researchers agree to construct the body of the research on the bases of target industry healthcare and financing subsystems in Jordan which has certain demographic characteristics, briefing almost the health delivery and financing systems with the focus on health expenditure trends within the governmentfunded health services to be compared at neighborhood, regional and international levels. The reason of typically 
to check whether the government of Jordan keep up financing the rapid increase in healthcare cost taking a toll since the 1990 s with almost $26 \%$ of the total cost of publicly provided health services are proportionate to contributors, and the other $74 \%$ of the entire costs lies over the government shoulders. It is obviously clear that the government of Jordan would not be able to carry an overwhelming burden of costs, and it works as a Health Maintenance Organization (HMO) for almost of two-third of the populace, subsequently, the rationale of this report is to investigate options for exempting the Jordanian government shape losing yearly. The report anticipated to look out various options open over efficiency besides transference of healthcare cost payment from contributors (publicly insured population especially those at the military side who pays in flat rates) and changing healthcare delivery and financing systems framework.

\section{The Jordanian Demographic Profile}

Jordan is a country of limited natural resources, a low middle-income country, and a high population growth rate. Table 3 shows the projected number of populations which has been increased from 5.4 million in 2003 to 10.2 million in 2018 with refugees. The population growth rate $3.2 \frac{16}{}$ reflects that the reproduction level in the country is too high in comparison with the advanced countries. The high fertility ratio of 3.5 children per woman and the low mortality rate coupled with the number of migrant populations from the neighboring countries especially
Syria and Iraq have increased the number of populations to 10.24 in $2018 ., \underline{6,17}-19$

Jordan has restricted resources with a high increment rate. The annual statistical report issued by the Department of Statistics in Jordan showed that the portion of the population less than 15 ages increased within the early of 2003 and are declined since then, unlike those between 15-65 age groups. The pattern is typical of a population that's increasing a fertility decline. With population ages 65 and above remaining about the same during the entire period (3.5, 3.45 respectively), the dependency ratio calculated as the ratio of persons in the "dependent" ages (Less than 15 years and over than 65 Years) was high in 2003 and decreased in 2017/8 (PPW, 2018). According to the Department of Statistics projections, the dependency ratio is projected to fall further to 33 in $2050 . \underline{6}, \underline{17}, \underline{20}, \underline{21}$

As within the Table 3 , the dependency ratio is projected to decline to, this with the increasing proportion of the population that's aging besides the epidemiological transition (changing in epidemiological profile) may have serious implications on the demand of healthcare services within the future. $\underline{18,19,22,2 \underline{2}}$

\section{Healthcare Financing and Delivery System}

Jordan as a low middle-income country with a population of about ten million is split into twelve governorates, which are sorted recently into three regions.

Table 3. Projected population by specific age groups

\begin{tabular}{|c|c|c|c|c|c|c|}
\hline \multirow[t]{2}{*}{ Year } & \multirow[t]{2}{*}{ Total population (000) } & \multicolumn{2}{|c|}{ Children $<15$ years } & \multicolumn{2}{|c|}{ Elderly 65> } & \multirow[t]{2}{*}{ Dependency ratio } \\
\hline & & Total (000) & $\%$ & Total (000) & $\%$ & \\
\hline 2003 & 5.48 & 2.08 & 38 & 0.19 & 3.5 & 71 \\
\hline 2008 & 6.13 & 2.14 & 34.9 & 0.26 & 4.2 & 68 \\
\hline 2013 & 8.114 & 2.15 & 31.9 & 0.33 & 4.9 & 67 \\
\hline 2016 & 9.798 & 3.36 & 34.3 & 0.36 & 3.7 & 65 \\
\hline 2018 & (7.98) 10.24 & 3.55 & 34.68 & 0.35 & 3.45 & 66 \\
\hline 2019 & 8.08 & 2.19 & 29.5 & 0.37 & 5.0 & 53 \\
\hline 2025 & 8.54 & 2.07 & 25.9 & 0.24 & 5.3 & 45 \\
\hline 2030 & 9.10 & 2.67 & 29.4 & 0.53 & 5.9 & 40 \\
\hline 2050 & 11.71 & 2,93 & 25.1 & 1.20 & 10.3 & 33 \\
\hline
\end{tabular}

Sources: Jordan, Higher Health Council Report, 2017; Jordan Statistics Yearbook, 2016 \& 2017; and, PopulationPyramid.net: https://www.populationpyramid.net/ jordan $/ 2050 /$ 
The Jordanian healthcare system could be an advanced mixture of extremely fragmented public and private health programs. There are two major public programs, the Ministry of Health $(\mathrm{MOH})$ and the Royal Medical Services (RMS), that each finance and deliver healthcare services to concerning roughly $70 \%$ of the population. $\underline{16}, \underline{24}-\underline{26}$. Additionally, there are smaller public programs including university-based programs (Jordan University Hospital and King Abdullah the First/ Jordan University of Science and Technology Hospital), the center for diabetes and endocrinology and genetics, and other NGOs i.e., United Nations Relief and Works Agency (UNRWA) which offer primary healthcare services to some of the Palestinian refugees, and King Hussein Cancer Center and charity association clinics.,$\underline{1, \underline{1}-10}$ The country's health reports i.e., $\mathrm{MOH}$ shows quick access and reasonable distribution of primary healthcare facilities across geographical and remote areas. Preventive (from $\mathrm{MOH}$ only) and therapeutic services are provided fairly and compared favorably with international standards. The establishment of recent national vaccination programs policies have helped in several progresses against communicable diseases i.e., eradication of polio in $1992,100 \%$ immunization rate of measles; and, Jordan is a free country from cholera, malaria, and schistosomiasis. Cross-border refugees have exhibited a burden on the country's strategic goals i.e., getting rid of secondhand tuberculosis by $2025 . \underline{13}, \underline{14}, \underline{26}-\underline{28}$

The new and reemerged diseases and epidemics are perplexing variables that led to reform the national immunization program, institution of the electronic monitoring system and the application of the accurate, sensitive system of controlling of infectious diseases such as AIDS, TB., diarrheal, and respiratory diseases. Whereas, cardiovascular, diabetes and cancer constitute the main problems in the country. $\underline{10,15,27}$

Secondary and tertiary health care provided in Jordan in an exceedingly provision of extremely specialized services and somehow compared favorably with international standards.

\section{Health Expenditures}

Like other lower middle-income countries, Jordan provides information on expenditures by source and uses of healthcare expenditures. The National Health Account (NHA) proclaimed that Jordan spends annually on individual health doubled of the disbursal within the middle-income countries between 205-2014 (Table 1).

The total health expenditures of the public sector raised from $60.78 \%$ in 2008 to $65.75 \%$ in 2013 (Table 2), while dropped down from $38.24 \%$ to $31.75 \%$ in the private sector in the same period. This switch from private to the public sector was due to unaffordable payments to the cost of services in the private sector.

The total health spending as a percent of GDP has gradually decreased from $9,5 \%$ in 2009 to $8.7 \%$ in 2016 (Table 1). $\underline{24}, \underline{29}-\underline{31}$

\section{International Comparison of Health Expenditures}

It is troublesome to create cross-comparisons within the developing countries due to the absence of their national health accounts. Additionally, to it, completion of public expenditures is commonly incomplete, specifically in countries wherever governments are concerned in finance and delivering healthcare services. So, international comparisons will offer a helpful image of amole spending patterns. Jordan compared favorably with some developed world. And high if compared to different MENA and middle-income countries. $\underline{32}$

As evident in Table 4, not like the compared countries, the Jordanian total public expenditure has gone down by nearly about one percent from 2005 to 2014 (8.8 to 7.4) despite the numerous increases in capital investment and also within the quantity of diriment expenses. $\underline{29}-\underline{31}$

The distribution of expenses has modified solely slightly; and, the final trend seems to be a gradual decline within the proportion of recurrent expenditure and increase in capital investment that apparently due to overwhelming of public health facilities due to increase in variety of refugees from neighbour countries and cross boarders displaced population i.e. Syrian and Iraqis refugees. $\underline{12}, \underline{19,25}, \underline{33}, \underline{32}$

\section{Trends of Public and Private Health Expediters}

Most of the population, more or less $75 \%$, are seeking healthcare services at public facilities; and, the remaining $21 \%$ and $4 \%$ followed by private and missionary care facilities respectively. 
Table 4. Health expenditure, total (\% of GDP)

\begin{tabular}{|l|l|l|l|l|l|l|l|l|l|l|l|}
\hline & $\mathbf{2 0 0 5}$ & $\mathbf{2 0 0 6}$ & $\mathbf{2 0 0 7}$ & $\mathbf{2 0 0 8}$ & $\mathbf{2 0 0 9}$ & $\mathbf{2 0 1 0}$ & $\mathbf{2 0 1 1}$ & $\mathbf{2 0 1 2}$ & $\mathbf{2 0 1 3}$ & $\mathbf{2 0 1 4}$ & $\mathbf{2 0 1 5}$ \\
\hline High income country & 10.9 & $\mathbf{1 0 . 9}$ & $\mathbf{1 0 . 9}$ & 11.2 & 12.1 & 12.0 & 11.9 & 12.1 & 12.1 & 12.2 & \\
\hline Arab world & 3.5 & 3.5 & 3.6 & 3.5 & 4.5 & 4.1 & 4.0 & 4.3 & 4.6 & 4.8 & \\
\hline Egypt, Arab Rep. & 5.0 & 5.2 & 4.9 & 4.8 & 5.0 & 4.7 & 5.0 & 5.2 & 5.4 & 5.6 & \\
\hline Kuwait & 2.3 & 2. & 2.1 & 1.9 & 3.8 & 2.7 & 2.6 & 2.5 & 2.5 & 3.0 & \\
\hline Jordan & 8.8 & 8.0 & 8.3 & 8.7 & 9.5 & 8.4 & 8.3 & 8.0 & 7.2 & 7.4 & \\
\hline Lebanon & 8.4 & 8.8 & 8.9 & 8.0 & 7.4 & 7.1 & 7.1 & 6.9 & 6.6 & 6.3 & \\
\hline Iran, Islamic Rep. & 5.9 & 5.8 & 6.2 & 7.6 & 8.0 & 7.1 & 6.9 & 6.4 & 6.8 & 5.9 & \\
\hline Iraq & 4.1 & 2.9 & 3.6 & 3.9 & 4.6 & 3.8 & 3.3 & 5.2 & 5.9 & 5.5 & \\
\hline Saudi Arabia & 3.4 & 3.5 & 3.4 & 2.8 & 4.0 & 3.4 & 3.5 & 3.8 & 4.2 & 4.6 & \\
\hline Sudan & 3. & 3.9 & 4.7 & 8.1 & 8.0 & 7.9 & 8.0 & 8.2 & 8.4 & 8.4 & \\
\hline Syrian Arab Republic & 4.1 & 3.7 & 3.7 & 3.3 & 3.5 & 3.2 & 3.2 & 3.2 & 3.2 & 3.2 & \\
\hline Low-income countries & 5.6 & 5.9 & 5.5 & 5.5 & 5.9 & 6.4 & 6.2 & 5.9 & 5.7 & 5.7 & \\
\hline $\begin{array}{l}\text { Lower-middle income } \\
\text { countries }\end{array}$ & 4.2 & 4.2 & 4.3 & 4.3 & 4.4 & 4.2 & 4.2 & 4.3 & 4.5 & 4.4 & \\
\hline Low \& middle income & 5.3 & 5.2 & 5.2 & 5.4 & 5.8 & 5.6 & 5.5 & 5.6 & 5.7 & 5.7 & \\
\hline Middle East \& North Africa & 4.3 & 4.2 & 4.2 & 4.1 & 5.3 & 5.0 & 4.8 & 5.0 & 5.1 & 5.3 & \\
\hline
\end{tabular}

Source: NHA, 2015

Publichealth expediters had increased by $10 \%$ from 2005 to 2014 Table 4). In 2014, the general public expenditures were $5.1 \%$ of GDP. This share of expenditures within the health sector as a percent of GDP is sort of high, though it remains almost like that of different regional countries. If Jordan compared at the extent of middle-income countries, it's the very best rate of expenditures on health with a proportion rate of $7.4 \%$ of GDP. If Jordan compared with and therefore the Middle East and Northern African countries, in terms of health expenditures share it expands quite $.06 \%$ of Middle-Income countries, the $3 \%$ of Lower Middle-Income countries, and the $1.7 \%$ of the LowIncome countries (Table 4). $\underline{29}$

The government remains a big supplier of health services. The government's role in the funding of health expenditures has been increasing from $4.7 \%$ in 2005 to 5.1 in 2014 (Table 5). During the same period, the share of the Ministry of Health ( $\mathrm{MOH})$ has remained regarding a similar at about $60 \%$ of the total government expenditures. There has been additional fluctuation within the shares of the Royal Medical Services (RMS) and also the universities primarily based programs.

Jordan lies within the middle of the spectrum of the Middle East and North African (MENA) countries in terms of GDP and GDP per capita. However, as evident in Table 5, in terms of expenditures on healthcare, Jordan surpasses most of the MENA countries. Jordan spends slightly more than 7.4 percent of its GDP on healthcare, nearly doubled the regional average. Public expenditure as a share of total health spending is higher in Jordan than most countries in the region. $\underline{29, \underline{32}}$

The annual out-of-pocket health expenditure is sharply decreased from JD86.2 in 2005 to JD68.8 in 2014. As in Table 6, it compared higher with high and low-income countries (JD35.3 and 64.5 respectively) and fewer favorably than the Arab World (JD81.6) and Middle-East and Northern African countries (JD79.1). Just about three-quarters of the overall out-of-pocket expenditure is spent on medications particularly chronic health conditions. $\underline{34}$

The poor folks in Jordan pay a bigger portion of their financial gains on health quite the wealthy. $\underline{35}$

Generally, equity within the health sector refers to reducing discrepancy within the health status or access to health services among whole completely different socioeconomic, ethnic, geographic or gender. Whereas, financial gain inequities noted the distribution of financial gain from the wealthy to the poor. 
Table 5. Health expenditure, public \& private (\% of GDP)

\begin{tabular}{|c|c|c|c|c|c|c|c|c|c|c|c|c|}
\hline & & 2005 & 2006 & 2007 & 2008 & 2009 & 2010 & 2011 & 2012 & 2013 & 2014 & 2015 \\
\hline \multirow{2}{*}{$\begin{array}{l}\text { High } \\
\text { incomecCountry }\end{array}$} & Pub. & 6.6 & 6.6 & 6.6 & 6.9 & 7.6 & 7.5 & 7.5 & 7.5 & 7.5 & 7.6 & \\
\hline & Pri. & 4.3 & 4.3 & 4.2 & 4.2 & 4.5 & 4.4 & 4.4 & 4.5 & 4.5 & 4.5 & \\
\hline \multirow[t]{2}{*}{ Arab world } & Pub. & 2.1 & 2.1 & 2.1 & 2.1 & 2.8 & 2.4 & 2.5 & 2.6 & 2.8 & 3.0 & \\
\hline & Pri. & 1.4 & 1.3 & 1.4 & 1.4 & 1.7 & 1.6 & 1.5 & 1.7 & 1.7 & 1.8 & \\
\hline \multirow[t]{2}{*}{ Egypt, Arab Rep. } & Pub. & 1.9 & 2.2 & 2.0 & 2.0 & 2.0 & 1.8 & 1.9 & 1.9 & 2.0 & 2.1 & \\
\hline & Pri. & 3.0 & 2.9 & 2.9 & 2.7 & 2.9 & 2.9 & 3.0 & 3.3 & 3.4 & 3.4 & \\
\hline \multirow[t]{2}{*}{ Kuwait } & Pub. & 1.8 & 1.8 & 1.6 & 1.5 & 3.3 & 2.3 & 2.2 & 2.1 & 2.1 & 2.6 & \\
\hline & Pri. & 0.4 & 0.4 & 0.4 & 0.4 & 0.4 & 0.4 & 0.3 & 0.3 & 0.3 & 0.4 & \\
\hline \multirow[t]{2}{*}{ Jordan } & Pub. & 4.7 & 4.4 & 4.9 & 5.4 & 6.6 & 5.9 & 5.9 & 5.5 & 4.8 & 5.1 & \\
\hline & Pri. & 4.1 & 3.5 & 3.3 & 3.3 & 2.8 & 2.4 & 2.4 & 2.4 & 2.3 & 2.2 & \\
\hline \multirow[t]{2}{*}{ Lebanon } & Pub. & 3.7 & 3.5 & 3.7 & 3.1 & 3.1 & 2.7 & 2.7 & 3.2 & 3.0 & 3.0 & \\
\hline & Pri. & 4.6 & 5.1 & 5.1 & 4.9 & 4.3 & 4.4 & 4.3 & 3.7 & 3.5 & 3.3 & \\
\hline \multirow[t]{2}{*}{ Iran, Islamic Rep. } & Pub. & 2.3 & 2.5 & 2.4 & 2.4 & 2.8 & 2.6 & 2.4 & 2.6 & 2.7 & 2.8 & \\
\hline & Pri. & 3.7 & 3.3 & 3.4 & 3.8 & 4.7 & 5.3 & 4.6 & 4.2 & 3.7 & 4.0 & \\
\hline \multirow[t]{2}{*}{ Iraq } & Pub. & 2.7 & 1.9 & 2.5 & 2.9 & 3.4 & 2.8 & 2.4 & 3.2 & 3.7 & 3.3 & \\
\hline & Pri. & 1.3 & 1.0 & 1.1 & 0.9 & 1.1 & 0.9 & 0.8 & 1.9 & 2.2 & 2.2 & \\
\hline \multirow[t]{2}{*}{ Saudi Arabia } & Pub. & 2.4 & 2.6 & 2.5 & 1.8 & 2.7 & 2.2 & 2.4 & 2.7 & 3.1 & 3.4 & \\
\hline & Pri. & 0.9 & 0.9 & 0.9 & 0.9 & 1.2 & 1.2 & 1.0 & 1.1 & 1.1 & 1.1 & \\
\hline \multirow[t]{2}{*}{ Sudan } & Pub. & 1.0 & 1.2 & 1.5 & 2.6 & 2.3 & 2.6 & 2.5 & 1.8 & 1.8 & 1.8 & \\
\hline & Pri. & 2.0 & 2.6 & 3.2 & 5.5 & 5.6 & 5.2 & 5.4 & 6.3 & 6.5 & 6.6 & \\
\hline \multirow[t]{2}{*}{ Syrian Arab Republic } & Pub. & 2.0 & 1.8 & 1.7 & 1.5 & 1.6 & 1.5 & 1.5 & 1.5 & 1.5 & 1.5 & \\
\hline & Pri. & 2.0 & 1.9 & 1.9 & 1.8 & 1.9 & 1.7 & 1.7 & 1.7 & 1.7 & 1.7 & \\
\hline \multirow{2}{*}{$\begin{array}{l}\text { Low-income } \\
\text { countries }\end{array}$} & Pub. & 2.4 & 2.6 & 2.2 & 2.3 & 2.4 & 2.6 & 2.6 & 2.5 & 2.3 & 2.4 & \\
\hline & Pri. & 3.2 & 3.3 & 3.2 & 3.2 & 3.5 & 3.8 & 3.6 & 3.4 & 3.3 & 3.3 & \\
\hline \multirow{2}{*}{$\begin{array}{l}\text { Lower-middle } \\
\text { income countries }\end{array}$} & Pub. & 1.4 & 1.5 & 1.5 & 1.5 & 1.6 & 1.5 & 1.5 & 1.6 & 1.6 & 1.6 & \\
\hline & Pri. & 2.8 & 2.7 & 2.7 & 2.7 & 2.8 & 2.7 & 2.7 & 2.7 & 2.8 & 2.8 & \\
\hline \multirow{2}{*}{$\begin{array}{l}\text { Low \& middle } \\
\text { income }\end{array}$} & Pub. & 2.4 & 2.4 & 2.5 & 2.7 & 2.9 & 2.8 & 2.8 & 2.9 & 2.9 & 3.0 & \\
\hline & Pri. & 2.8 & 2.7 & 2.6 & 2.7 & 2.8 & 2.7 & 2.6 & 2.7 & 2.7 & 2.7 & \\
\hline \multirow{2}{*}{$\begin{array}{l}\text { Middle East \& North } \\
\text { Africa }\end{array}$} & Pub. & 2.4 & 2.4 & 2.4 & 2.3 & 3.0 & 2.7 & 2.7 & 2.8 & 3.0 & 3.2 & \\
\hline & Pri. & 1.9 & 1.7 & 1.8 & 1.8 & 2.2 & 2.3 & 2.1 & 2.1 & 2.0 & 2.1 & \\
\hline
\end{tabular}

Source: NHA, 2015

\section{Public Sector Health Insurance Premiums}

Public servant's premium contributions vary across the general public systems (MOH, RMS, JUST/JUH, and UNRWA). The monthly premiums subtracted from all civil services workers of $3 \%$ of their gross salaries up to the limit of $30 \mathrm{JD}$ are beyond the cap, therefore, funding becomes regressive since these cover about $21 \%$ of the overall cost of the health services they received. Whereas the military theme, all the military personnel are paying a monthly flat rate of $2.4 \mathrm{JD}$, that appears to 
Table 6. Annual out-of-pocket health expenditure (\% of private expenditure on health)

\begin{tabular}{|c|c|c|c|c|c|c|c|c|c|c|c|}
\hline & 2005 & 2006 & 2007 & 2008 & 2009 & 2010 & 2011 & 2012 & 2013 & 2014 & 2015 \\
\hline High income country & 36.6 & 36.75 & 36.9 & 37.3 & 36.5 & 36.6 & 36.8 & 36.1 & 35.8 & 35.3 & \\
\hline Arab world & 83.4 & 84.0 & 84.6 & 84.2 & 83.7 & 82.2 & 81.3 & 81.7 & 81.7 & 81.6 & \\
\hline Egypt, Arab Rep. & 98.2 & 98.0 & 97.7 & 97.3 & 96.8 & 95.7 & 93.6 & 90.0 & 90.0 & 90.0 & \\
\hline Kuwait & 90.5 & 90.5 & 90.5 & 90.5 & 90.5 & 90.5 & 90.5 & 90.5 & 90.5 & 90.5 & \\
\hline Jordan & 86.2 & 88.4 & 89.4 & 83.5 & 75.8 & 73.4 & 70.1 & 69.1 & 68.9 & 68.8 & \\
\hline Lebanon & 77.1 & 75.2 & 73.4 & 71.9 & 73.1 & 73.1 & 74.7 & 69.5 & 69.5 & 69.5 & \\
\hline Iran, Islamic Rep. & 89.2 & 88.5 & 88.3 & 86.6 & 87.2 & 86.7 & 85.2 & 81.2 & 81.2 & 81.2 & \\
\hline Iraq & 100 & 100 & 100 & 100 & 100 & 100 & 100 & 100 & 100 & 100 & \\
\hline Saudi Arabia & 59.9 & 61.3 & 60.8 & 58.6 & 60.6 & 56.4 & 54.3 & 54.9 & 55.5 & 56.1 & \\
\hline Sudan & 88.9 & 91.3 & 92.9 & 95.8 & 95.8 & 95.8 & 95.8 & 95.8 & 96.0 & 96.0 & \\
\hline Syrian Arab Republic & 100 & 100 & 100 & 100 & 100 & 100 & 100 & 100 & 100 & 100 & \\
\hline Low-income countries & 73.4 & 70.9 & 71.1 & 70.7 & 67.7 & 65.1 & 64.9 & 66.1 & 64.2 & 64.5 & \\
\hline $\begin{array}{l}\text { Lower-middle income } \\
\text { countries }\end{array}$ & 88.5 & 88.1 & 88.2 & 87.9 & 87.8 & 87.0 & 87.2 & 86.7 & 87.1 & 87.2 & \\
\hline Low \& middle income & 79.3 & 78.3 & 77.7 & 78.0 & 77.8 & 75.7 & 75.6 & 75.9 & 76.0 & 75.1 & \\
\hline $\begin{array}{l}\text { Middle East \& North } \\
\text { Africa }\end{array}$ & 83.7 & 83.3 & 83.5 & 82.3 & 82.6 & 81.7 & 80.7 & 79.5 & 79.3 & 79.1 & \\
\hline
\end{tabular}

Source: NHA, 2015

be a lot of regressive across the opposite public programs since their contributions cowl below $5 \%$ of the total cost of the health services they received. In general, the public health programs serve as Health Maintenance Organization (HMO) to the general public servants and their dependents who represent about two-thirds of the

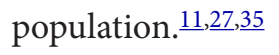

\section{The Analysis}

Wellbeing is the main driver of our quality of life. The glob focuses currently each day on inputs (8Ms: money, materials, manpower, management, methods, means, manufactures, milieu) to provide healthcare. World expenditures are exaggerated for the last two decades. Jordan is that the largest country within the heterogeneous region that spends a lot of, and over the Arab world, East Asia and Pacific, Latin American countries, least developed world, Middle-East and North African Countries; and, less than the World (9.9) and Euro Area, European Union and closed to Europe and Central Asia countries. $\underline{32}$

Contrasting the High-Income countries and Low Middle-Income countries Jordan public share of health funding is far higher whereas the role of out-of-pocket expenditure (Table 6) is above the High-income countries, less than Egypt, Kuwait, Lebanon, Iraq, Low-Income, lower-Middle Income, Low and Middle Income, and Middle-East and North African Countries.

As healthcare is judged in terms of needs (PublicRight) instead of ability and willingness to pay, Jordan should give healthcare to all in Y2025 despite public or private disbursement, insured population or non-insured, etc. ( $48 \%$ public employees, able to pay $46 \%$, poor $6 \%$ ). Not like the developed world, the insurance coverage is expanding, the $48 \%$ lined by insurance remained stable whereas health expenditures are rapidly increased since the 1990s. The coverage of insurance embodied people who are affiliated to health insurance similarly as those having free access to healthcare provided by the government i.e., the poor $(6 \%)$. Health insurance programs run by the Jordanian government is steady a challenge like those in most low-income countries. ${ }^{11,27}$ The relationship between health outcomes and healthcare payment represents the most indicator of large return within the investment of healthcare. $\underline{5}, \underline{10}$

Jordan as a rustic while not assistances by international health channels has a remarkable development of health focus areas of Infant and child mortality, maternal 
mortality HIV/AIDS, malaria and tuberculosis. This obviously appears from life expectancy at births which are improved from 69.8 in the 1990s (Table 7) to 74.3 in 2016. It's above many the neighboring and regional countries i.e., World average, Arab World, Middle-East and North Africa, Egypt, Iraq, and Yemen Rep. and compared favorably with East Asia and Pacific, and Latin America and Caribbean countries. $\underline{32}, \underline{36}$

Also, in terms of infant mortalities, Table 8, Jordan includes a higher indicator of decreasing the infant mortality rate per thousand live births form 29.9 in the 1990s to 15.1 in 2016 than Egypt, Iraq, Yemen, Arab world, World average, Least developed, Middle-East, South Asia, and Sub-Sharan African countries. $\underline{10}, \underline{32}$

Correspondingly, the crude death rate (Table 9) has been ablated from 5.06 per thousand population to 3.8 that place Jordan higher than Egypt, Iraq, Yemen, World's Average, Arab World, East Asia Pacific, Euro Area, European Union, Europe and Central Asia and the remainder of the compared international countries. $\underline{10}, \underline{32}$

Similarly, in terms of maternal mortality, Table 10, Jordan encompasses a higher indicator of decreasing the maternal mortality rate per hundred thousand live births form 110 in the 1990s to 58 in 2015 than Yemen, the Arab world, World average, Least developed, Middle-East, South Asia, and Sub-Sharan African countries. 12,37

As can be seen in Table 1 the trend of health expenditures as a percent of value decreased sharply from 9.6 in the 1990s to 6.2 in 2014, however, it has plateaued in 2015 (9.6) and star to decrease all over again in 2016. Considering this fluctuated rhythm in spending that incorporates a bigger weight in Jordan as a low-income country, the recent change in trend is very problematic for the poorest as they magnified in numbers. $\underline{12, \underline{37}}$ Regarding the previous shut disruption of Jordan's healthcare funding systems, some queries could arias themselves to resolve the system's pitfalls: can the system will fit the new demands being placed by its high rate of growth and therefore the epidemiologic transitions?

Will the Jordanian economy still support and supply ever-increasing amounts of health resources to the health sector within the absence of efficiency gains? Can costeffective measures be taken that sustainability improves health outcomes? In outline, Is that the Jordanian healthcare funding system viable and sustainable within the predictable future? $, \underline{7}, \underline{19}, \underline{38}$

It ought to be noted that the health sector performs well in several regards, however with inefficiencies with

Table 7. Life expectancy at birth (total, male and female)/years

\begin{tabular}{|c|c|c|c|c|c|c|c|c|c|c|c|c|c|}
\hline \multirow{2}{*}{$\begin{array}{l}\text { Comparison } \\
\text { countries-international } \\
\text { Arab World }\end{array}$} & \multirow{2}{*}{$\begin{array}{l}\frac{\text { Year }}{2016} \\
28.6\end{array}$} & \multirow{2}{*}{$\begin{array}{l}\text { Neighboring } \\
\text { and regional } \\
\text { countries } \\
\text { comparison }\end{array}$} & \multicolumn{11}{|l|}{ Years } \\
\hline & & & ฉ & ¿্ণ & 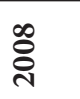 & ஓ્ণ & 을 & ন্ণ & בับ & ᄅ্ণ & 离 & in & ֶֻ) \\
\hline East Asia \& Pacific & 71.1 & \multirow[t]{2}{*}{ Egypt } & \multirow{2}{*}{64.5} & \multirow{2}{*}{68.6} & \multirow{2}{*}{69.9} & \multirow{2}{*}{70.1} & \multirow{2}{*}{70.3} & \multirow{2}{*}{70.5} & \multirow{2}{*}{70.7} & \multirow{2}{*}{70.9} & \multirow{2}{*}{71.1} & \multirow{2}{*}{71.3} & \multirow{2}{*}{71.4} \\
\hline Euro area & 74.5 & & & & & & & & & & & & \\
\hline European Union & 81.5 & \multirow[t]{2}{*}{ Iraq } & \multirow{2}{*}{66.1} & \multirow{2}{*}{69.1} & \multirow{2}{*}{68.1} & \multirow{2}{*}{68.2} & \multirow{2}{*}{68.4} & \multirow{2}{*}{68.7} & \multirow{2}{*}{68.9} & \multirow{2}{*}{69.2} & \multirow{2}{*}{69.4} & \multirow{2}{*}{69.6} & \multirow{2}{*}{69.8} \\
\hline Europe \& Central Asia & 80.6 & & & & & & & & & & & & \\
\hline $\begin{array}{l}\text { Latin America \& } \\
\text { Caribbean }\end{array}$ & 77.2 & Jordan & 69.8 & 71.7 & 73.0 & 73.2 & 73.4 & 73.5 & 73.7 & 73.8 & 74.0 & 74.1 & 74.3 \\
\hline $\begin{array}{l}\text { Least developed } \\
\text { countries: UN } \\
\text { classification }\end{array}$ & 75.5 & Kuwait & 72.0 & 73.1 & 73.7 & 73.8 & 73.9 & 74.0 & 74.2 & 74.3 & 74.4 & 74.5 & 74.6 \\
\hline $\begin{array}{l}\text { Middle East \& North } \\
\text { Africa }\end{array}$ & 64.4 & Oman & 67.1 & 72.1 & 75.1 & 75.4 & 75.6 & 75.9 & 76.1 & 76.3 & 76.5 & 76.8 & 77.0 \\
\hline OECD members & 73.4 & Qatar & 74.9 & 76.2 & 77.0 & 77.1 & 77.3 & 77.4 & 77.5 & 77.7 & 77.8 & 78.0 & 78.1 \\
\hline South Asia & 80.1 & Saudi Arabia & 69.0 & 72.4 & 73.3 & 73.4 & 73.5 & 73.7 & 73.8 & 74.0 & 74.2 & 74.4 & 74.5 \\
\hline Sub-Saharan Africa & 68.7 & Yemen Rep. & 57.8 & 60.3 & 62.8 & 63.2 & 63.5 & 63.7 & 64.0 & 64.2 & 64.5 & 64.7 & 64.9 \\
\hline World & 60.3 & & & & & & & & & & & & \\
\hline
\end{tabular}

Source: World Bank, 2018 
Table 8. Infant mortality rate/1000 live births

\begin{tabular}{|c|c|c|c|c|c|c|c|c|c|c|c|c|c|}
\hline \multirow{2}{*}{$\begin{array}{l}\text { Comparison } \\
\text { countries-international }\end{array}$} & \multirow{2}{*}{$\begin{array}{l}\text { Year } \\
2016 \\
28.6\end{array}$} & \multirow{2}{*}{$\begin{array}{l}\text { Neighboring and } \\
\text { regional countries } \\
\text { comparison }\end{array}$} & \multicolumn{11}{|c|}{ Years } \\
\hline & & & Дั & ஓ્ণ & 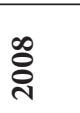 & ஓ्रे & 율 & ت로 & ำ & $\stackrel{n}{\frac{1}{2}}$ & ন্ণ & $\overbrace{0}^{\frac{4}{2}}$ & $\stackrel{0}{\stackrel{4}{2}}$ \\
\hline East Asia \& Pacific & 13.5 & \multirow[t]{2}{*}{ Egypt } & \multirow[b]{2}{*}{63} & \multirow[b]{2}{*}{37.3} & \multirow[b]{2}{*}{26.3} & \multirow[b]{2}{*}{25.3} & \multirow[b]{2}{*}{24.3} & \multirow[b]{2}{*}{23.4} & \multirow[b]{2}{*}{22.5} & \multirow[b]{2}{*}{21.6} & \multirow[b]{2}{*}{20.9} & \multirow[b]{2}{*}{20.1} & \multirow[b]{2}{*}{19.4} \\
\hline Euro area & 3.05 & & & & & & & & & & & & \\
\hline European Union & 3.4 & \multirow[t]{2}{*}{ Iraq } & \multirow{2}{*}{42.4} & \multirow{2}{*}{36} & \multirow{2}{*}{31.4} & \multirow{2}{*}{30.8} & \multirow{2}{*}{30.2} & \multirow{2}{*}{29.5} & \multirow{2}{*}{28.9} & \multirow{2}{*}{28.2} & \multirow{2}{*}{27.4} & \multirow{2}{*}{26.7} & \multirow{2}{*}{25.9} \\
\hline Europe \& Central Asia & 8.3 & & & & & & & & & & & & \\
\hline $\begin{array}{l}\text { Latin America \& } \\
\text { Caribbean }\end{array}$ & 13.8 & Jordan & 29.9 & 23.4 & 19 & 18.5 & 18 & 17.5 & 17 & 16.5 & 16 & 15.5 & 15.1 \\
\hline $\begin{array}{l}\text { Least developed countries: } \\
\text { UN classification }\end{array}$ & 48.14 & Kuwait & 15.1 & 11 & 9.7 & 9.5 & 9.2 & 8.9 & 8.5 & 8.2 & 7.8 & 7.5 & 7.2 \\
\hline $\begin{array}{l}\text { Middle East \& North } \\
\text { Africa }\end{array}$ & 20.11 & Oman & 31.8 & 14.3 & 10.3 & 10.1 & 10 & 9.9 & 9.8 & 9.6 & 9.5 & 9.3 & 9.2 \\
\hline OECD members & 5.9 & Qatar & 17.8 & 10.8 & 8.1 & 7.9 & 7.7 & 7.6 & 7.5 & 7.4 & 7.4 & 7.4 & 7.3 \\
\hline South Asia & 38.8 & Saudi Arabia & 35.8 & 18.8 & 14.4 & 14 & 13.5 & 13.1 & 12.7 & 12.3 & 11.9 & 11.4 & 11.1 \\
\hline Sub-Saharan Africa & 53.25 & Yemen Rep. & 88.4 & 68.9 & 47.2 & 45.2 & 43.8 & 43.3 & 43.2 & 43.2 & 43.2 & 43.2 & 43.2 \\
\hline World & 30.5 & & & & & & & & & & & & \\
\hline
\end{tabular}

Source: World Bank, 2018

Table 9. Crude death rate/1000 population

\begin{tabular}{|c|c|c|c|c|c|c|c|c|c|c|c|c|c|}
\hline \multirow{3}{*}{$\begin{array}{l}\text { Comparison } \\
\text { countries-interna- } \\
\text { tional }\end{array}$} & \multirow{3}{*}{\begin{tabular}{|l|}
2016 \\
5.548
\end{tabular}} & \multirow{3}{*}{$\begin{array}{l}\text { Neighbor- } \\
\text { ing and } \\
\text { regional } \\
\text { countries } \\
\text { comparison }\end{array}$} & \multirow{2}{*}{\multicolumn{11}{|c|}{ Years }} \\
\hline & & & & & & & & & & & & & \\
\hline & & & ڤั & ঠి & : & ஓి & 을 & $\overline{1}$ & 离 & $\stackrel{\text { m }}{\mathscr{0}}$ & ग) & in & ำ \\
\hline East Asia \& Pacific & 7.306 & Egypt & 8.406 & 6.487 & 6.273 & 6.241 & 6.206 & 6.166 & 6.121 & 6.071 & 6.017 & 5.963 & 5.909 \\
\hline Euro area & 9.846 & & & & & & & & & & & & \\
\hline European Union & 10.039 & Iraq & 6.996 & 5.575 & 5.7 & 5.652 & 5.578 & 5.484 & 5.381 & 5.279 & 5.183 & 5.096 & 5.02 \\
\hline $\begin{array}{l}\text { Europe \& Central } \\
\text { Asia }\end{array}$ & 10.013 & & & & & & & & & & & & \\
\hline $\begin{array}{l}\text { Latin America \& } \\
\text { Caribbean }\end{array}$ & 5.960 & Jordan & 5.064 & 4.126 & 3.889 & 3.878 & 3.867 & 3.857 & 3.848 & 3.84 & 3.834 & 3.829 & 3.828 \\
\hline $\begin{array}{l}\text { Least developed } \\
\text { countries: UN } \\
\text { classification }\end{array}$ & 7.685 & Kuwait & 2.561 & 2.527 & 2.54 & 2.541 & 2.545 & 2.554 & 2.571 & 2.597 & 2.633 & 2.681 & 2.739 \\
\hline $\begin{array}{l}\text { Middle East \& } \\
\text { North Africa }\end{array}$ & 4.963 & Oman & 5.483 & 3.518 & 2.895 & 2.845 & 2.799 & 2.754 & 2.709 & 2.663 & 2.618 & 2.574 & 2.533 \\
\hline OECD members & 8.372 & Qatar & 2.166 & 2.018 & 1.61 & 1.568 & 1.534 & 1.51 & 1.496 & 1.491 & 1.495 & 1.509 & 1.531 \\
\hline South Asia & 7.085 & Saudi Arabia & 4.935 & 3.737 & 3.597 & 3.587 & 3.572 & 3.557 & 3.543 & 3.534 & 3.533 & 3.54 & 3.557 \\
\hline $\begin{array}{l}\text { Sub-Saharan } \\
\text { Africa }\end{array}$ & 9.231 & Yemen Rep. & 11.472 & 9.09 & 7.4 & 7.234 & 7.088 & 6.958 & 6.842 & 6.735 & 6.636 & 6.543 & 6.456 \\
\hline World & 7.648 & & & & & & & & & & & & \\
\hline
\end{tabular}

Source: World Bank, 2018 
Table 10. Maternal mortality ratio (estimate per 100,000 live births)

\begin{tabular}{|c|c|c|c|c|c|c|c|c|c|c|c|c|c|}
\hline \multirow{2}{*}{$\begin{array}{l}\begin{array}{l}\text { Comparison } \\
\text { countries-international }\end{array} \\
\text { Arab World }\end{array}$} & Year & \multirow{2}{*}{$\begin{array}{l}\text { Neighboring } \\
\text { and regional } \\
\text { countries } \\
\text { comparison }\end{array}$} & \multicolumn{11}{|c|}{ Years } \\
\hline & $\begin{array}{l}2016 \\
156\end{array}$ & & ฉั & ঠి & 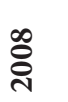 & ஓి & 웅 & 룽 & $\underset{\text { ก }}{\stackrel{4}{7}}$ & $\stackrel{n}{2}$ & $\underset{⿱ 亠}{ \pm}$ & 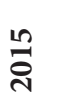 & ס) \\
\hline East Asia \& Pacific & 59 & \multirow[t]{2}{*}{ Egypt } & \multirow{2}{*}{106} & \multirow{2}{*}{63} & \multirow{2}{*}{45} & \multirow{2}{*}{43} & \multirow{2}{*}{40} & \multirow{2}{*}{39} & \multirow{2}{*}{37} & \multirow{2}{*}{35} & \multirow{2}{*}{34} & \multirow{2}{*}{33} & \\
\hline Euro area & 6 & & & & & & & & & & & & \\
\hline European Union & 8 & \multirow[t]{2}{*}{ Iraq } & \multirow{2}{*}{107} & \multirow{2}{*}{63} & \multirow{2}{*}{52} & \multirow{2}{*}{52} & \multirow{2}{*}{51} & \multirow{2}{*}{51} & \multirow{2}{*}{51} & \multirow{2}{*}{50} & \multirow{2}{*}{50} & \multirow{2}{*}{50} & \\
\hline Europe \& Central Asia & 16 & & & & & & & & & & & & \\
\hline $\begin{array}{l}\text { Latin America \& } \\
\text { Caribbean }\end{array}$ & 67 & Jordan & 110 & 77 & 58 & 58 & 59 & 59 & 59 & 59 & 59 & 58 & \\
\hline $\begin{array}{l}\text { Least developed countries: } \\
\text { UN classification }\end{array}$ & 436 & Kuwait & 7 & 7 & 6 & 5 & 5 & 4 & 4 & 4 & 4 & 4 & \\
\hline $\begin{array}{l}\text { Middle East \& North } \\
\text { Africa }\end{array}$ & 81 & Oman & 30 & 20 & 18 & 18 & 18 & 18 & 18 & 18 & 18 & 17 & \\
\hline OECD members & 14 & Qatar & 29 & 24 & 17 & 17 & 16 & 15 & 14 & 13 & 13 & 13 & \\
\hline South Asia & 182 & $\begin{array}{l}\text { Saudi } \\
\text { Arabia }\end{array}$ & 46 & 23 & 15 & 14 & 14 & 13 & 13 & 12 & 12 & 12 & \\
\hline Sub-Saharan Africa & 547 & $\begin{array}{l}\text { Yemen } \\
\text { Rep. }\end{array}$ & 547 & 440 & 417 & 417 & 416 & 413 & 410 & 406 & 398 & 385 & \\
\hline World & 216 & & & & & & & & & & & & \\
\hline
\end{tabular}

Source: World Bank, 2018

a significant portion (about one third) of the population with no formal coverage. Since some health outcomes are good health indicator i.e. IMR (0.015), MMR (0.00058) and Per Capita Health Expenditures., they might be improved with none any increase within the expenditures. The rapid increase in the unregulated private sector and the more and more budget affected the public sector runs the danger. $\underline{6}$

In some countries, the owed (private payments), as a direct outlay created by households, represent a very important part of funding their healthcare systems. Whereas, in Jordan, the annual out-of-pocket health expenditure is sharply faded from JD86.2 in 2005 to JD68.8 in 2014. As in Table 6, it compared higher with low-income countries (JD64.5) and fewer favorably than the Arab World (JD81.6) and Middle-East and Northern African countries (JD79.1). Just about threequarters of the overall out-of-pocket expenditure spent on medication, particularly chronic health conditions. In High-income countries, the outlays represent a little fraction of expenditures on healthcare, in contrast to the low-income countries that account for most of the funding of their healthcare. The worldwide trend is as per capita income increases the share of out-of-pocket and external assistance decreases. $10, \underline{32}$

To sum up, the govt. of Jordan wouldn't be ready to continue providing the health services at this trend: a fast increase in demand over publicly funded services inside the absence of efficiency gains; and, infeasible and not sustainable within the predictable future. $\underline{26,31,19, \underline{38}}$

This article presupposed to spotlight the importance of reallocation strategy (reform) to form upon the strength of the public and private sectors, improve efficiency, access, equity, improve quality of care, and enhance patient satisfaction and long-term financial sustainability. These view issues need a direct intervention coupled with monitoring programs to fast (unstable) increase within the share of GDP to health that rises the problem of sustainable spending and efficiency. With regard to the previous issue, Jordan appears unable to continue spending rhythm primarily biased returns to health (26\%). Whereas, the later could also be witnessed by reengineering the investment in curative and primary healthcare that is able to curtail spending 
on curative (little prevention is better than huge cure) and alter the perspective of those who are able to pay to use extraordinarily backed health services at public facilities. $2 \underline{12,36,38,39}$ In addition, there to utilize a numerous dogma problem as mentioned below:

\subsection{Efficiency in Public Spending}

Effectiveness and efficiency in delivering healthcare services are crucial indicators to the attainment of health goals at the country level as well as health for all strategy in the year 2025 (with the thought of poor). There has been a significant enlargement in all categories of medical and allied health personnel aside from nursing since 1994. The number of doctors had increased by $38 \%$ from 1.6 in the 1990 s to 3.4 per 1000 population today. Also, the number of pharmacists is quite doubled from 0.8 to 1.2 . Whereas the number of nurses has remittent by $7 \%$ since the 1990s, that might have a negative consequence on the standard of care provided as well as on costs. It's like that plenty of nurses had a much better alternative within the golf and neighboring countries.. There are 110 hospitals and quite 13731 beds within the Hashemite Kingdom of Jordan, 2016. This suggests that there was the population/ bed ratio is 714 in 2016, which means that 2.3 per 1000 population, the public sector represents $63 \%$. The number of beds accumulated by $13 \%$ since 2008 that unbroken pace with the increase. $\underline{23}$

In scrutiny these internationally, a reasonable bed variety is seen and therefore the high number of doctors (4798 in 2016) which requires to be even. $\underline{\underline{23}}$

\subsection{Productive/Technical Efficiency}

The productive efficiency may even be assessed by the relation between the output and inputs. As per on top of information in tables the cost of delivery of health services aren't compared to the revenues at intervals the public sector i.e., public contributions to health services are $21 \%$ of the entire costs (public expenditures) within the civil servant and $5 \%$ of the military facet. $\frac{35}{\text { Th }}$ Th approximate accumulative $26 \%$ revenues compared to public expenditure 5.1 of GDP (Table 5) generated from the foremost composite of public servants (MOH, RMS) that serve about $70 \% 1, \underline{128}$ of the population represent the failure of Jordan's health system finance in terms of technical and/or productive efficiency.

The improvement in technical efficiency among the health sector will cause increase savings. Some changes among the production possibility carve i.e., redistribution of scarce of productive resources (reallocation basically based on international standards, quality accreditation, equity and geographical distribution of the population) will result in cut back duplications, fragmentation, and restricted access to a bound segment of the Jordanian population. The proper usage of obtainable refined technology i.e. CAT scanners, Cath labs, etc. will shift the production possibility frontier and then to an increase in productivity.,$\underline{7,37}$

\subsection{Allocative Efficiency}

Allocative efficiency considers the distribution of output. Allocation of resources such isn't attainable, by reallocating resources, to create one individual at an advantage while not making at least one other individual worse off.

There has been no enough information to calculate the average cost per patient per day within the systemwide to pinpoint the clear feature of allocative efficiency in primary, secondary, tertiary and rehabilitative sides to facilitate or generate reallocation strategy to regulate clear options of maldistribution of the scarce of productive resources available in the health sectors.

\subsection{Economic Efficiency}

Economic efficiency is the relationship between the inputs and cost. There has been no accessible information across the health sub-sectors to research the economic efficiency, particularly at the public sector level and more specifically at RMS (military facilities).

\subsection{Social Efficiency}

A change within the allocation of resources is socially efficient if the total benefits of those who gain outweigh the total loss of those who lose.

Jordan contains a well-developed delivery health system with a significant quantity of capacity. Therefore, financial and physical access isn't a serious drawback to get required health services, save the localized problems i.e., rural geographic areas which can rectify by the restructuring reform methods.

\subsection{Horizontal Efficiency}

The proportion of those needing the service to who truly receives it represents the horizontal efficiency. 
It refers to the aptitude of the country continued increasing the coverage of health services (preventive and curative) among the limit of financial resources and infrastructure, high cost of services, deficiencies within the current health system i.e. trads-off. re-organizational structure, health service system integration (public and private partnership and global financing mechanism), decongestion of unnecessary demand (especially with those who are insured in public sector and therefore the main causes of the services abuse) and incentives to be incorporated within the health delivery system will certainly affecting the mode of delivery also as quality and efficiency of health service delivery. Recognizing the trade-offs and considering them can facilitate in selectivity and prioritization health of services to the total population in efficient and effective manners..,$\underline{10}$

\subsection{Vertical Efficiency}

The proportion of services provided that attend those who need them instead of those who don't. The vertical enlargement of health programs is more expensive than horizontal ones since thus the need for more resources and management from regular programs. They also may provide short-run resolution permitting Jordan to shelve urgently required healthcare delivery and financing systems reforms. Trad-offs in both vertical and horizontal efficiency may be managed in the reestablishment of the objectives of the healthcare delivery and financing systems. The public financing health services in Jordan ought to pay a lot of attention to the trade-offs; as a poorly supported sub-health system, it's totally different incentives to in choosing vertical or horizontal packages of health services to the whole population. $\underline{40}$ Despite the spectacular infrastructure and capabilities of the Jordanian healthcare financing and delivery systems offered, a rigorously enforced reform strategy can do the clearest answers to the launched queries. $\underline{40,41}$

\subsection{Financing Universal Coverage}

To be clear and specific, developing and implementing universal coverage policies isn't a straightforward and political endeavor with major economic implications. The universal coverage is that the basic goal of all health systems across the world. $1 . \underline{42}-\underline{44}$

Approximately concerning $80 \%$ of the population in Jordan features formal coverage within the public and private sectors. As being mentioned before, the bulk of the population has access to the Ministry of Health facilities, together with the poor peoples. $\frac{45}{}$ In effect, the $\mathrm{MOH}$ provides insurance policy with no premiums and also the contributions cover about $21 \%$ of the total cost of services delivered with the $\mathrm{MOH}$ facilities, and the rest of the cost is financed through the MOH budget. Given this high grant to the uninsured who use the $\mathrm{MOH}$ facilities, the low contribution levels in terms of premiums and price sharing of those covered under the Civil Insurance and also the Royal Medical Services Systems, the shortage of unjust relationship between these payments and ability to pay, and also the current high level of health outlay, Jordan might improve the equity of its finance systems and supply formal universal coverage at a bit extra value..$\underline{4,47}$ This extra quantity of cash may be obtained through a relatively small change in the Civil Insurance and RMS premiums and cost-sharing structures, changes within the $\mathrm{MOH}$ rate settings additionally to the economic gains in alternative areas i.e., delivery system and the pharmaceutical sectors. $\underline{15,27, \underline{35}}$

The major issue facing funding and population coverage area unit are: unavailable, and lack of accurate health information system that's the most obstacle awaiting the reform strategy; one third of the population are uninsured who have access to public facilities and exemptions from the royal court, prime ministries, and others whereas not providing any contributions; no standardized contribution rates from the insured within the public sector, failure to affix the publicly funded health subsystems below one management to scale back duplications and avoid fragmentations within the valuable health services, absence of laws to force health delivery and funding system unification and unify subscriptions to realize correct utilization of services (prevent abuse); and lack of turning out with for the design for National Health Insurance System since 1979, $\underline{8}, 9, \underline{11}, \underline{43}$

\section{Conclusion}

The government of Jordan wouldn't be ready to continue providing health services at the present trend: a fast increase in demand over publicly funded services within the absence efficiency gains; not viable (unsustainable) within the predictable future.

This study spotlights the importance of reallocation methods (reforms) to create upon the strength of the 
public and private sector; utilize six types of efficiency, improve quality of care and increase accessibility; and, enhance patient satisfaction and long-term financial sustainability. A prompt intervention coupled with monitoring programs to the rapid (unstable) increase in percentage share of GDP to health that rises the difficulty of sustainable spending and efficiency, is inevitable.

The wider public insurance coverage is contributed to the rise in spending; possibly over half of the increase has arisen from developments on the availability facet (supply-side). This, in turn, suggests that the most target of policy ought to be there to slow the expansion of public health disbursal through macro-instruments.

Developing a replacement health funding policy issue and with attainable intervention and observance mechanisms are that major downside facing the Jordanian health system now a day.

Jordan spends $8.7 \%$ of GDP (2016) on health that compared somehow favorably with the developed world and therefore the world average, and better than neighboring, MENA, Arab world, Latin America \& Caribbean, and Sub-Saharan countries. As in Table 1, this vast portion of the national piece of cake (budget), is stable in a very rise fashion since the 1990s, which yields some development in health outcomes i.e., IMR \&MMR. The matter rises presently is that will Jordan still provide such massive portion in conjunction with low-contributions to health $(26 \%)$, economic recession and inefficiency within the overall system of health i.e., duplication of services (curative), system fragmentation, limited access of services to certain segment of population, waste of scarce of productive resources, poor referral system, rapid growth private sector ..etc. In addition to that, the under-spending in primary and preventive healthcare, the opportunity cost and cost-effective measures to draw who will pay to use the public facilities who chose private providers rather than free and extremely sponsored public facilities.

Jordan ought to beat raising funds, increase the streams of funds from its current i.e., unified public insurance mechanisms, impose insurance coverage at the country level; utilize investment methods in health to ensure perpetual delivery of health to all. This, in addition, to figure seriously on productive and/or technical efficiency to maximize output of effective health services; economic efficiency to provide services at lease costs; and, apportion resources towards services of highest value or optimizing the mix of health services to get the foremost health value for the neediest and so maximize returns. Reduce spending on curative care and increase preventive measures i.e., Road Traffic Accidents (RTAs) that represent the ordinal causes of death and core health problems, obesity, immunization, and family planning, to curtail spending on curative care. Build public-private partnership health programs to comprehend extra economic gains. Improve efficiency within the excessive use of medications (abusers) to prevent self-purchasing drugs and encourage the utilization of generic medicine.

One of the foremost forgone alternatives available to health suppliers is that the cost-containment strategy to manage public payment and monitor 'medical behavior' i.e., demand-pull and cost-push inflation.

Improve the standard of public facilities by adopting national and international certification programs will facilitate redirecting the utilization of private health towards public facilities.

\section{Recommendations}

Findings suggested that there was a progressive impact of the reform on healthcare supplying and finance systems once contributor's expenses are used to build it; however, due to comparability issues between the five main suppliers, the findings don't seem to be conclusive.

Great attention ought to be created to health constitutions, five main providers to health with duplication, fragmentation, and limited access to a certain segment of the population, and waste of resources, that square measure the foremost rationalization of rising health expenditures. Merging health subsystems beneath one umbrella in terms of service delivery and finance is badly-needed and promptly required policy currently each day.

The severe financial burden over the government shoulder may be mitigated by adopting the national health insurance system and resolved relating to $80 \%$ of the Jordanian healthcare system's financial problems.

Pay great attention to the six varieties of efficiencies, effectiveness and quality measures.

Monitor the healthcare system at facility levels with a specific focus on elder and gate-keepers (family physicians) to reduce secondary and tertiary care abuses, and decongestions.

Develop an accurate health management information system at the national level to rectify obstacles at hand health supplying and financing reforms. 
Lastly, a broad outline of potential economic reforms at intervals the supply of publicly supported health services is much recommended.

\section{Conflict of Interest}

We attest that we have no conflict of interest to declare and contributed significantly to study.

\section{Acknowledgements}

The original proposal of this article was submitted to the deanship of scientific research at Yarmouk University and the Ministry of Health in Jordan for backing, however regrettably we have a tendency of not so succeeded. We are terribly grateful to the Ministry of Health and Royal Medical Services ICT personnel for their contributions to our approach.

\section{Ethical Issues}

There are no ethics issues within the research. The Ethics and postgraduate studies committees in the department of basic health sciences and public administration - faculty of medicine \& faculty of economics and administrative sciences approved the proposal of this article.

\section{Authors' Contributions}

$\mathrm{AR}$ and $\mathrm{RT}$ formulated the research design, prepare the data for analysis and composed the essential draft of the article. AZ and IZ validate the overall comparison faceted and reformulated the article plan, taken part within the elucidation of the results and favouring the in general setting.

\section{References}

1. Health system profile: Jordan. [cited 2006]. http://apps. who.int/medicinedocs/documents/s17296e/s17296e.pdf.

2. Second national millennium development goals report Jordan. [cited 2010 Aug 29]. http://www.jo.undp.org/ content/jordan/en/home/library/mdg/publication_1.html.

3. How much do OECD countries spend on health?[cited 2017 Dec 15]. https://www.oecd-ilibrary.org/social-issuesmigration-health/how-much-do-oecd-countries-spendon-prevention_f19e803c-en.

4. Sustainable development goals: 17 goals to transform our world. [cited 2015]. http://planning.kar.nic.in/docs/
SDG/17\%20Goals\%20to\%20transform\%20our\%20World. pdf.

5. The worldwide governance indicators: methodology and analytical issues. [cited 2010]. https://openknowledge. worldbank.org/handle/10986/3913.

6. Trends in demographic and health indicators in Jordan: data from the 1990-2012 Jordan population and family health surveys. [cited 2014]. https://dhsprogram.com/ pubs/pdf/TR8/TR8.pdf.

7. The Hashemite Kingdom of Jordan High Health Council/ General Secretariat. [cited 2013]. http://www.hhc.gov.jo/ uploadedimages/HRHReport2013.pdf.

8. The Hashemite Kingdom of Jordan The High Health Council. [cited 2015]. http://www.hhc.gov.jo/uploadedimages/ The $\% 20$ National $\% 20$ Strategy $\% 20$ for $\% 20$ Health $\%$ 20Sector\%20in\%20Jordan\%202015-2019.pdf.

9. The National Strategy for Health Sector in Jordan 20162020. [cited 2016]. http://www.nationalplanningcycles.org/ sites/default/files/planning_cycle_repository/jordan/ national_strategy_for_health_sector_2016-2020_jordan. pdf.

10. The World Bank in Jordan. [cited 2018]. https://www. worldbank.org/en/country/jordan/overview.

11. Technical report. [cited 2019 Oct 05]. https://en.wikipedia. org/wiki/Technical_report.

12. Futuretrendsinhealthcareexpenditures. [cited2017].https:// www.oecd-ilibrary.org/social-issues-migration-health/ future-trends-in-health-care-expenditure_247995bb-en.

13. $\mathrm{MOH}$ Ministry of Health of Jordan, annual report. [cited 2011]. http://www.health.gov.ff/wp-content/uploads/2014/ 09/Annual-Report-2011.pdf.

14. The Hashemite Jordan of Kingdom Ministry of Health. [cited 2012]. https://www.moh.gov.jo/Echobusv3.0/ SystemAssets/eaa84873-ea12-48d9-bc94-5016c323a8bd. pdf.

15. The Hashemite Jordan of Kingdom Ministry of Health. [cited 2016].https://www.moh.gov.jo/Echobusv3.0/SystemAssets/ debff26b-c6df-4244-b7f6-4244cdf58733.pdf.

16. International bank for reconstruction and development project, appraisal document on proposed financing. [cited 2017 May 30]. http://documents.worldbank.org/curated/ en/331761497578505275/pdf/Jordan-Emergency-HealthPAD-06022017.pdf.

17. National strategy for reproductive health/family planning (2013-2017). [cited 2013]. https://data2.unhcr.org/en/ documents/download/39905.

18. Annual statistical report. [cited 2016]. https://www.undp. org/content/undp/en/home/procurement/business/ annual-statistical-report.html.

19. Progressing the sustainable development goals through health in all policies. [cited 2017]. https://www.who.int/social_ determinants/publications/Hiap-case-studies-2017/en/. 
20. Jordan statistics yearbook. [cited 2017]. http://dosweb.dos. gov.jo/ar/product-category/dhs-ar/.

21. National Human Resources for Health Observatory Jordan's HRH report 2015. [cited 2015]. http://www.hhc. gov.jo/uploadedimages/HRH\%20Report\%202015.pdf.

22. Population pyramid of the world from 1950 to 2100 . [cited 2018]. https://www.populationpyramid.net/jordan/2050/.

23. Jordan statistics yearbook (JSY). [cited 2016]. http:// dosweb.dos.gov.jo/ar/analytical-reports/health_reports/.

24. Jordan health system profile. [cited 2011 Aug]. https://www. researchgate.net/publication/292135260_Jordan_Health_ System_Profile2010.

25. Defining and measuring fairness in financial contribution to the health system. [cited 2013]. https://www.who.int/ healthinfo/paper24.pdf.

26. Jordan National Health Sector strategy 2015-2019. [cited 2015]. https://jordankmportal.com/resources/jordannational-health-sector-strategy-2015-2019.

27. The Hashemite Jordan of Kingdom Ministry of Health. [cited 2013]. https://moh.gov.jo/Echobusv3.0/SystemAssets/ d64fe777-550a-4f62-83db-6245eb2e40b9.pdf.

28. Public Expenditure perspectives. [cited 2015]. DAI, (2015). Public Expenditure Perspectives Update (2015-2017) Working Paper on Health Sector.

29. Public Expenditure Perspectives. [cited 2017]. https:// repositorio.cepal.org/bitstream/handle/11362/42062/1/ S1700766_en.pdf

30. Jordan national health accounts 2013 technical report no. 6.[cited 2016 Apr]. http://www.hhc.gov.jo/uploadedimages/ NHA\%202013.pdf.

31. The socio-economic implications of Syrian refugees on Jordan: a cost-benefit framework. [cited 2014]. https:// www.kas.de/einzeltitel/-/content/the-socio-economicimplications-of-syrian-refugees-on-jordan.

32. Global economic inequality. [cited 2018]. https:// ourworldindata.org/global-economic-inequality.

33. Jordan national health accounts 2013 technical report no. 6. [cited 2013]. http://www.hhc.gov.jo/uploadedimages/ NHA\%202013.pdf.

34. Analyzing equity in health utilization and expenditure in Jordan. [cited 2015]. https://thinkwell.global/wp-content/ uploads/2016/10/Thinkwell-Jordan-Report-FINAL_ August31.pdf.

35. High Health Council. [cited 2018]. http://hhc.gov.jo/ uploadedimages/c685537a-c123-483c-b1b5-66c0975fc02a. pdf.
36. Investing in medication adherence improves health outcomes and health system efficiency. [cited 2018]. https:// www.oecd-ilibrary.org/social-issues-migration-health/ investing-in-medication-adherence-improves-healthoutcomes-and-health-system-efficiency_8178962c-en.

37. Analyzing equity in health utilization and expenditure in Jordan with focus on maternal and child health services. [cited 2016]. https://thinkwell.global/wp-content/uploads/ 2016/10/Thinkwell-Jordan-Report-FINAL_August31.pdf.

38. Second national millennium development goals report Jordan 2010. [cited 2010 Aug 29]. http://www.jo.undp.org/ content/jordan/en/home/library/mdg/publication_1.html.

39. UNICEF annual report 2016. [cited 2016]. https://www. unicef.org/about/annualreport/files/Jordan_2016_COAR. pdf.

40. Horizontal and vertical delivery of health services : what are the trade offs (English). [cited 2005]. http://documents. worldbank.org/curated/en/914491468761944686/ Horizontal-and-vertical-delivery-of-health-services-whatare-the-trade-offs.

41. Technical reports with the MOH. [cited 2017]. https:// www.moh.gov.jm/annual-reports/.

42. World health report: health systems financing: the path to universal coverage. [cited 2010]. https://www.who.int/ whr/2010/en/.

43. Health systems financing and the path to universal coverage. [cited 2012]. https://www.who.int/bulletin/volumes/88/6/ 10-078741/en/.

44. Ministry of Health Strategic Plan 2013-2017. [cited 2012]. https://jordankmportal.com/resources/ministry-of-healthstrategic-plan-2013-2017.

45. Towards universal health coverage: a comprehensive review of the health financing system in Jordan. [cited 2014]. https://scholar.harvard.edu/eozcelik/publications/towardsuniversal-health-coverage-comprehensive-review-healthfinancing-system.

46. Health care coverage in OECD countries in 2012. [cited 2016 May 25]. http://www.oecd.org/officialdocuments/ publicdisplaydocumentpdf/? cote=DELSA/HEA/WD/ HWP(2016)11\&docLanguage $=$ En .

47. Which policies increase value for money in health care? [cited 2018 Mar 07]. https://www.oecd-ilibrary.org/socialissues-migration-health/which-policies-increase-valuefor-money-in-health-care_a46c5b1f-en. 